\title{
EFFECT OF PROTEIN LEVEL AND STOCKING DENSITY ON GROWTH PERFORMANCE, SURVIVAL RATE, FEED UTILIZATION AND BODY COMPOSITION OF NILE TILAPIA FRY (OREOCHROMIS NILOTICUS L.)
}

\author{
Yassir A. E. Khattab ${ }^{1}$, Mohsen Abdel-Tawwab ${ }^{2}$ and Mohammad \\ H. Ahmad ${ }^{1}$ \\ ${ }^{1}$ Fish Nutrition Department and ${ }^{2}$ Fish Ecology Department, \\ Central Laboratory for Aquaculture Research, Abbassa, Abo- \\ Hammad, Sharkia, Egypt.
}

Key words: Protein level, stocking density, fish growth, Nile tilapia, feed utilization and body composition.

\section{ABSTRACT}

$\mathbf{T}$ his study was carried out to evaluate the growth response of Nile tilapia; O.niloticus $L$. to dietary protein levels at two stocking densities. This study was bifactorial designed ( 3 protein levels $\times 2$ stocking densities). Fish (1.8-2.5 g/fish) was randomly distributed into the aquaria at a rate of 15 or $30 \mathrm{fish} / 100 \mathrm{~L}$. The temperature was adjusted at $27 \pm 1{ }^{\circ} \mathrm{C}$. Fish of each density were fed either a diet containing $25 \%, 35 \%$ or $45 \% \mathrm{CP}$ with a feeding rate of $4 \%$ of body weight twice daily for 5 days a week for 70 days.

The obtained results showed that the final body weight, weight gain, weight gain \%, specific growth rate (SGR)were positively affected by protein level and inversely affected by stocking density, but not affected by their interaction. Condition factor was significantly affected only with dietary protein levels $(\mathrm{P}<0.05)$, while survival rate did not differ significantly by protein levels or stocking densities. The maximum growth was obtained with $45 \% \mathrm{CP}$ at low density $(10.1$ $\mathrm{g} / \mathrm{fish}$ ), whereas the lowest growth was obtained with $25 \% \mathrm{CP}$ at high density $(6.4 \mathrm{~g} / \mathrm{fish})$. On the other hand, the reduced growth at high density could be recovered by increasing the protein level.

Feed intake increased significantly with increasing dietary protein level only $(P<0.01)$. Feed conversion ratio $(F C R)$, protein efficiency ratio (PER) and protein productive value (PPV) were significantly affected by protein level and stocking density $(P<0.01)$. The best FCR was obtained with $45 \%$ protein diet at low density (1.72) and with $35 \%$ under low density (1.81) with insignificant 
(1.72) and with $35 \%$ under low density (1.81) with insignificant difference $(\mathrm{P}>0.05)$. The highest values of PER and PPV were obtained with $2.5 \% \mathrm{CP}$ at low (1.913 and $30.54 \%$, respectively) and high density $(1.720$ and $26.64 \%$, respectively) with significant uifference $(\mathrm{P}<0.01)$.

Moisture was significantly affected by protein level only $(\mathrm{P}<0.05)$, while crude protein, total lipids and ash were significantly affected by protein level and stocking density. The highest protein content in fish body was obtained with $45 \% \mathrm{CP}$ at low and high densities $(58.0 \%$ and $57.9 \%$, respectively; $\mathrm{P}>0.05)$. The highest content of body lipids was observed in fish fed $25 \%$ protein diet at low and high densities (32.8 and $31.0 \%$, respectively; $\mathrm{P}>0.05$ ). The highest content of carcass ash was noticed in fish fed $45 \%$ protein diet at low and high densities with significant difference $(15.6 \%$ and $16.8 \%$, respectively; $\mathrm{P}<0.05$ ).

\section{INTRODUCTION}

Tilapias are of the most important fish species for aquaculture all over the world (El-Sayed, 1999) and represent the species of choice due to their high growth rate, significant tolerance to environmental stress, easy of reproduction, and perhaps their unquestionable market demand. Nile tilapia (Oreochromis niloticus), in particular is widely accepted to Egyptian consumers.

Intensification of tilapia culture is a good solution for increasing fish production, and to optimize fish intensification, both feed quality and stocking density should be considered. Addition of artificial feeds plays an important role especially under conditions of heavy stocking, when natural feed supply has declined or completely disappeared. The added feeds should be rich in protein, carbohydrate and fats, and should also contain vitamins, minerals and growthpromoting substances to be physiologically balanced (Huisman et al., 1979). However, the fish malnutrition would reduce growth performance and may cause disease or even death (Lovell, 1989). So, it is essential to develop suitable feeds to be used either as a stipplementary diet in ponds or as a complete diet in tanks.

Protein is the most critical and/or costly ingredient in tilapia feeds, where protein sources represent about $60 \%$ or more of the cost of fish feeds. So optimal utilization of dietary proteins is essential for 
economical production (Andrews, 1977). The level of dietary protein producing maximum growth of tilapia depends upon the protein quality, energy content of the diet, the physiological state of the fish, age, reproductive state, and the environmental factors such as temperature, salinity ...etc (Lovell, 1989).

In aquaculture, fish size and production determine the price of fish, which in turn depends on the growth. Subsequently, control of size and production are two important tasks to meet the market demands, and increasing the stocking density is a way of dealing with problem of land shortage and increasing fish intensification. Stocking density is an important factor to take into account when ranking families or progeny groups for growth performance. In many cultivated fish species, growth is inversely related to stocking density and this is mainly attributed to social interactions (Holm et al., 1990; Haylor, 1991; Miao, 1992; Huang and Chiu, 1997; Canario et al, 1998; Irwin et al., 1999; Silva et al., 2000). However, social interactions through competition for food and/or space can negatively affect fish growth. On the other hand, the price of fish is determined by the market demand of supply (size and production), that in turn depends on their growth. Papst et al. (1992) suggested that in intensive aquaculture the stocking density is an important factor that determines the economic viability of the production system.

A close relationship has been found between stocking density, growth of Africa catfish Clarias gariepinus (Burchell) fry (Haylor, 1991) and redtail shrimp Penaenus penicillatus (Alock) (Miao, 1992). Moreover, Wallace et al. (1988) reported that high density culture reduced size variation in the early stage of Arctic charr (Salvelinus alpinus (Linnaeus), but Papst et al., (1992) recorded that density had no effect on the size (weight) variation in juvenile Arctic charr. The objective of this study was to evaluate the effects of protein levels at two stocking densities on growth performance, survival rate, feed utilization and body composition of Nile tilapia fry $(O$. niloticus $\mathrm{L}$.).

\section{MATERIAL AND METHODS}

This study was carried out at the Central Laboratory for Aquaculture Research, Abbassa, Abou Hammad, Sharkia Governoratc. Lgypt. Nile tilapia (O.niloticus L.) were collected from 
Abbassa Hatchery, General Authority for Fish Resources Development. Fish size was $1.8-2.5 \mathrm{~g} /$ fish; the batch of fish was kept in indoor trough tanks for two weeks as an acclimatization period. Fish were fed on a commercial diet containing $25 \%$ protein during the acclimatization period. Fifty fish were frozen at $-20^{\circ} \mathrm{C}$ for analysis of body chemical composition.

This study was bifactorial designed ( 3 protein levels $\times 2$ stocking densities). Fish with mixed sex were graded and randomly distributed into the aquaria at two stocking densities (15 and 30 fish/aquarium, respectively). Each aquarium containing $100 \mathrm{~L}$ of wellaerated tap water. Each aquarium was supplied with compressed air from air pump via air stones. The temperature was adjusted at $27 \pm 1^{\circ} \mathrm{C}$ by using thermostatically controlled heaters. Aquaria of each density were fed either a diet containing $25 \%, 35 \%$ or $45 \% \mathrm{CP}$ with a feeding rate of $4 \%$ of life body weight twice daily for 5 days a week for 70 days. Three aquaria were assigned for each protein level treatment within each fish stocking density. Feed formulation and chemical composition of each diet are presented in Table (1). Fish faeces of each aquarium were removed daily by siphoning about $50 \%$ of water volume of each aquarium and replaced by well-aerated tap water. Dead fish were removed and recorded daily. Fish in each aquarium was biweekly weighed and subsequently the amount of the given feed was calculated.

At the end of experiment period (70 days), fish were removed, counted and weighed. Different growth parameters and parameters of feed utiliwere calculated as described by Ahmad (200). Five fishes from each aquarium were taken to carry out chemical analysis of the fish body. Chemical analysis of feed ingredients, experimental diets and fish carcasses were carried out according to the methods of $\mathrm{AOAC}$ (1990). Moisture was determined by drying oven at $85^{\circ} \mathrm{C}$ until fixed weight. Crude protein was determined by Kjeldahl method (total nitrogen $x$ 6.25). Total lipids (ether extract) were determined by Soxhlet extraction method using petroleum ether for $16 \mathrm{hrs}$. Ash was determined by ashing the samples in muffle furnace at $550{ }^{\circ} \mathrm{C}$ for 6 hrs. Crude fiber was estimated according to Goering and Van Soest (1970). Growth energy of diet and fish carcass were estimated according to NRC (1993).

Data of growth periormance, survival rate, feed utilization and chemical composition of fish body were subjected lo two-way 
ANOVA according to Snedecor and Cochran (1982). Differences between means were deduced using Duncan's new multiple range tests (Duncan, 1955).

\section{RESULTS}

The different growth parameters (final body weight, weight gain, weight gain \%, specific growth rate (SGR) of Nile tilapia $(O$. niloticus) fed with 25,35 or $45 \%$ protein diets at low and high densities are shown in Table (2). The obtained results show that the different growth parameters were significantly affected by protein level and stocking density $(\mathrm{P}<0.05)$, but not their interaction. Condition factor was significantly affected only with dietary protein levels $(\mathrm{P}<0.05)$, while survival rate did not differ significantly at protein level or stocking density (Table 2).

It is also noticed that fish growth was positively affected by protein level and inversely affected by stocking density. The maximum growth was obtained with $45 \% \mathrm{CP}$ at low density $(10.1 \mathrm{~g} / \mathrm{fish})$, whereas the lowest growth was obtained with $25 \% \mathrm{CP}$ at high density $(6.4 \mathrm{~g} / \mathrm{fish})$. On the other hand, the reduced growth under high density could be recovered by increasing the protein level. The weight gain of Nile tilapia at high density fed with $45 \%$ protein diet and that at low density fed with $35 \%$ protein diet was approximately the same $(7.0$ and $6.8 \mathrm{~g}$ /fish, respectively). Similarly, Nile tilapia at high density fed $35 \%$ protein diet gave the same weight gain $(5.5 \mathrm{~g})$ to that obtained by low density with $25 \%$ protein diet $(4.9 \mathrm{~g})$.

Results of feed intake, feed conversion ratio (FCR), protein efficiency ratio (PER) and protein productive value (PPV) of Nile tilapia ( $O$. niloticus) fed different protein levels at both densities are shown in Table 3. Feed intake increased significantly with increasing dietary protein level $(\mathrm{P}<0.01)$, but did not differ significantly at both stocking densities. Meanwhile, FCR, PER and PPV were significantly affected by protein level and stocking density $(P<0.01)$. The best FCR was obtained with $45 \%$ protein diet at low density (1.72) and with $35 \%$ under low density (1.81) with insignificant difference $(P>0.01)$, but the poorest FCR was obtained with $25 \%$ protein diet at low and high density (2.25 and 2.46, respectively). PER and PPV decreased with incresing protein level and stocking densities. The highest 
values of PER and PPV were obtained with $25 \% \mathrm{CP}$ at low $(1.913$ and $30.54 \%$, respectively) and high density (1.720 and $26.64 \%$, respectively) with significant difference $(\mathrm{P}<0.05)$. The lowest values of PER and PPV were obtained with the diet containing $45 \% \mathrm{CP}$ at low and high density (1.340 and 1.25 for PER and $20.88 \%$ and $19.82 \%$ for PPV, respectively) with insignificant difference $(\mathrm{P}>0.05)$.

Results of the chemical composition of whole body fish are shown in Table 4. Moisture was significantly affected by protein level only $(\mathrm{P}<0.05)$ and did not differ as affected by stocking density. Other chemical components (crude protein, total lipids and ash) were significantly affected by protein level and stocking density. The highest protein content in fish body was obtained with $45 \% \mathrm{CP}$ at low and high density $(58.0 \%$ and $57.9 \%$, respectively; $\mathrm{P}>0.05)$, while the lowest one was obtained with $25 \% \mathrm{CP}$ at low and high density (54.34\% and 55.0\%, respectively; $\mathrm{P}>0.05$ ). Carcass total lipids content decreased with increasing dietary protein level. The highest content of body lipids was existed in fish fed $25 \%$ protein diet at low and high density ( 32.8 and $31.0 \%$, respectively; $\mathrm{P}>0.05$ ), while the lowest one was obtained with fish fed $45 \%$ protein diet at low and high density (26.3 and 25.2\%, respectively; $\mathrm{P}>0.05$ ). The highest content of carcass ash was noticed in fish fed $45 \%$ protein diet at low and high density with significant difference $(15.6 \%$ and $16.8 \%$, respectively; $\mathrm{P}<0.05)$. Meanwhile, the lowest ones were obtained with fish fed $25 \%$ protein diet at low and high density with insignificant difference $(13.0 \%$ and $13.9 \%$, respectively; $\mathrm{P}>0.05$ ).

\section{DISCUSSION}

The amount of researches concerning different tilapia species has increased significantly in the last years, including many areas of interest for aquaculture because of the high importance of tilapias allover the world. The stocking density and the optimum protein level still attract the attention of researchers, because these factors aim to higher profit, but without significant losses in growth ratio and environmental quality. Furthermore, the growth of tilapia depends upon the stocking density, dietary protein quality, energy content of the diet, the physiological status of the fish, age, reproductive state, and the environmental factors such as temperature salinity:...etc (Lovell, 1989). 
Effect of protein level and stocking density on growth 201 performance, survival rate, feed utilization and body composition of Nile tilapia fry (Oreochromis niloticus L.)

It is important to take fish density into account when ranking families or progeny groups for growth performance, where fish density is an important factor affecting growth and maturation of wild and laboratory fish, besides food supply and its quality, genetics and environmental conditions (Smith et al., 1978). Also, fish density could affect the efficiency of food utilization, where larger number of fish stocked in a pond decreases the amount of feed available to each fish.(Chang, 1988).

In this study, there was significant reduction in growth $(\mathrm{P}<0.05)$ with increasing stocking density at all protein levels. This result is in agreement with Huang and Chiu (1997) who studied the effects of stocking density $(0.1,0.2,0.4,1.6$ and 3.2 fry/L.) for fry Nile tilapia, and found that the fish size and production were significantly affected by stocking density. Also, Canario et al. (1998) studied the effect of stocking density $\left(0.35,1.3\right.$ and $\left.3.2 \mathrm{~kg} / \mathrm{m}^{3}\right)$ on the growth of gilthead sea-bream, Sparus aurata, and found that fish in the highest density group grew $25 \%$ slower than fish in the lowest density group. Irwin et al. (1999) studied the effect of stocking density $(0.7,1.1,1.5$ and $1.8 \mathrm{~kg} / \mathrm{m}^{2}$ ) on the growth of turbot, Scophthalmus maximus for 45 days, and found that stocking density inversely affects growth rate and mean weights. Silva et al. (2000) also studied the effect of stocking density $\left(2,3\right.$ and $\left.4 \mathrm{~kg} / \mathrm{m}^{3}\right)$ on the growth of tetra-hybrid red tilapia, and found that final body weight gain was significantly higher at density of 2 and $3 \mathrm{~kg} / \mathrm{m}^{3}$, while the biggest biomass and feed consumption were observed at density of $4 \mathrm{~kg} / \mathrm{m}^{3}$. Moreover, other fish species showed an inverse relationship between stocking density and growth parameters, which were considered as the density dependent category, such as the cases found for Chinook salmon Oncorhynchus tshawytscha (Walbaum) (Martin and Wertheimer, 1989), Nile tilapia O. niloticus (Siddiqui et al., 1989; Rosa et al., 1990), African catfish (Haylor, 1991) and Arcatic charr, Salvelinus alpinus (JØrgensen et al., 1993).

In this study, the condition factor and survival rates were not affected significantly with stocking density, because the stocking density here was below the critical level, however, the fish were small sized and with no competition for space. Also, Huang and Chiu (1997) found that condition factor and survival rate were not 
affected significantly by stocking density. Moreover, the high survival rate of Nile tilapia at high density indicates its amenability to the intensive culture practice.

In the present study, the optimum dietary protein level for Nile tilapia fry reared at low and high density (15 and $30 \mathrm{fish} / 100 \mathrm{~L}$, respectively) wa $45 \%$ and $25 \%$ respectively. It is also noticed that, the reduced growth can be recovered by increasing dietary protein level. Fish require diets relatively high in protein content, because their poor utilization of carbohydrates as energy source, thus sufficient supply of dietary protein is needed for rapid growth (Lovell, 1989). This result is in agreement with other authors. Tacon (1987) found that dietary protein level was varying from $42 \%$ for fry to $35 \%$ for growing adult fish. Moreover, EL-Sayed and Teshima (1991) reported that the dietary protein requirements of several species of tilapia have been estimated to range from 20 to $56 \%$. Also, Al-Hafedh (1999) found that the better growth rate of Nile tilapia was obtained at high dietary protein levels (40-45\%) rather than $25-35 \%$ protein. On the other hand, Abdelghany (2000) and Khattab, et al. (2000) found that, the optimum dietary protein level for Nile tilapia was $35 \%$ and $37 \%$, respectively.

In this study, feed intake was significantly affected by protein level, but not by stocking density. JØrgensen et al. (1993) found that daily feed intake of Arctic charr (Salvelinus alpinus) at stocking densities of 100 and $200 \mathrm{fish} / \mathrm{m}^{3}$ was not significantly different. In this study, FCR decreased significantly $(\mathbf{P}<0.05)$ under low stocking density than high stocking density and the best FCR for Nile tilapia was obtained with $45 \%$ protein diet under low density. This result is in agreement with those obtained by Jauncey (1982), Ofojekwu and Ejike (1984) and De Silva and Perera (1985) who reported that FCR decreased with increasing dietary protein level. In this study, PER and PPV were affected by dietary protein level and stocking density, where their higher values were obtained under low density than high density. Dabrowski (1979) and De-Silva et al. (1989) found that PER decreased with increasing dietary protein content.

Contrarily, McGeachin et al. (1987) reported that growth of $O$. aureus (21.2 g average wt.) fed $36 \%$ protein diet in marine cages, where stocking densities of up to $300 / \mathrm{m}^{3}$ was not affected. Also, Siddiqui et al. (1989) reported no difference in growth or FCR of O. niloticus ( $40.3 \mathrm{~g}$ average wt) reared in brackish whter $(3.5-3.9$ 
Effect of protein level and stocking density on growth 203 performance, survival rate, feed utilization and body composition of Nile tilapia fry (Oreochromis niloticus L.)

ppt) tank for 164 days on a $34 \%$ protein diet at densities of 16,32 and $42.6 \mathrm{fish} / \mathrm{m}^{3}$.

On the other hand, Watanabe et al. (1990) showed that the growth and feed conversion of Florida red tilapia fed two protein levels (28 and 32\%) did not differ at densities ranging from 100 to $300 / \mathrm{m}^{3}$. Also, they found that final mean weight, daily weight gain, specific growth rate and survival rate were higher and FCR lower for fish fed the $28 \%$ protein diet than those fed $32 \%$ protein diet under all densities. Omar et al. (1997) found that growth performance of Nile tilapia fingerlings fed with 30 and $40 \%$ crude protein and stocking densities 10,30 and $40 \mathrm{fish} / 105 \mathrm{~L}$ was significantly reduced. At higher dietary protein level and stocking densities, feed and nutrient efficiency, it was also significantly reduced. These results clearly showed that fish growth was best at the lowest stocking density and low dietary protein level tested.

This study revealed that the reduced growth at high stocking density might be recovered by increasing the dietary protein level for Nile tilapia fry. The optimum dietary protein is $45 \%$ for intensive fish farming in Egypt, where it realized the optimum growth and feed utilization

\section{REFERENECES}

Abdelghany, A.E. (2000). Optimum dietary protein requirements for Oreochromis niloticus L. fry using formulated semi-purified diets. In: Tilapia Aquaculture in the $21^{\text {st }}$ Century. Proceedings from the $5^{\text {th }}$ International Symposium on Tilapia Aquaculture, K. Fitzsimmons and J.C. Filho (eds.). Vol. 1, pp 101-108, 3-7 Sept. 2000, Rio de Janeiro, Brazil.

Ahmad, M.H. (2000). Improve productive performance in fish. Ph.D. Dissertation, Animal Prod. Depart., Faculty of Agriculture, Zagazig University.

Al-Hafedh, Y.S. (1999). Effects of dietary protein on growth and body composition of Nile tilapia, Oreochromis niloticus L.. Aquacult. Res., 30(5): 385-393. 
Andrews, J.W. (1977): Protein requirements. In: Regional Research Project. Catfish production. Alabama Agricultural Experiment Station, University of Auburn, Al., USA, pp 10-13.

A.O.A.C. (1990). Official Methods of Analyses. 15th edition. K. Helrich (ed.). Association of Official Analytical Chemists Inc., Arlington, VA, USA.

Canario, A.V.M., Condeça, J., Power, D.M. and Ingleton, P.M. (1998). The effect of stocking density on growth in gilthead sea-bream, Sparus aurata (L.). Aquacult. Res., 29: 177-181.

Chang, W.Y.B. (1988): Fish production: Data synthesis and model development. In: Collaborative Research Support Program (CRSP), pond dynamic. Aquaculture $6^{\text {th }}$ annual administrative report, pp 41-49. Oregon State University, Oregon, USA.

Dabrowski, K. (1979). Feeding requirements of fish with particular attention to common carp, A review. Polish Arch. Hydrobiol., 26: $135-158$.

De Silva, S.S., Gunasekera, R.M. and Atapattu, D. (1989). The dietary protein requirements of young tilapia and an evaluation of the least cost of dietary protein levels. Aquacult., 80: 271-284.

De Silva, S.S. and Perera, M.K. (1985). Effects of dietary protein levels on growth, food conversion and protein use in young Tilapia nilotica at four salinities. Trans. Amer. Fish. Soc., 114: 584-589.

Duncan, D.B. (1955). Multiple range and multiple (F) test. Biometrics, 11: $1-42$.

El-Sayed A.-F.M. (1999). Alternative dietary protein sources for farmed tilapia, Oreochromis spp. Aquacult., 179: 149-168.

El-Sayed A.-F.M. and Teshima, S. (1991). Tilapia nutrition in aquaculture. Rev. Aquat. Sci., 5: 247-265.

Goering, H.K. and Van Soest, P.G. (1970). Forage fiber analysis (apparatus, reagent, procedures, and some applications). US Dept. Agric. Handbook, Washington D.C., USA, p. 379.

Haylor, G.S. (1991). Controlled hatchery production of Clarias gariepinus (Burchell 1922): growth and survival of fry at high stocking density. Aquacult. Fish. Manag. 22 $405+22$. 
Effect of protein level and stocking density on growth 205 performance, survival rate, feed utilization and body composition of Nile tilapia fry (Oreochromis niloticus L.)

Holm, J.C., Refstie, T. and Bo, S. (1990). The effect of fish density and feeding regimes on individual growth rate and mortain rainbow trout (Oncorhynchus mykiss). Aquacult., 89: 3-4.

Huang, W-B. and Chiu, T-S. (1997). Effects of stocking density on survival, growth, size variation, and production of Tilapia fry. Aquacult. Res., 28: 165-173.

Huisman E.J.; Breterler, M.. and Vismans, A. (1979). Retention of energy, protein, fat and ash in growing carp (Cyprinus carpio) under different feeding and temperature regimes. Proceeding World Symposium on Fish Nutrition and fish.

Irwin, S.; Halloran, J.O. and FitzGerald, R.D. (1999). Stocking density, growth and growth variation in juvenile turbot, Scophthalmus maximus (Rafinesque). Aquacult., 178: 77-88.

Jauncey, A. (1982). The effect of varying dietary protein level on the growth, food conversion, protein utilization and body composition of juvenile tilapias (Sarotherodon mossambicus). Aquacult., 27: 43-54.

JØrgensen, E.H.; Christiansen, J.S.; Jobling, M. (1993). Effects of stocking density on food intake, growth performance and oxygen consumption in Arctic charr (Salvelinus alpinus). Aquacult., 110: 191-204.

Khattab, Y.A.E., Ahmad, M.H., Shalaby, A.M.E. and Abdel-Tawwab, M. (2000). Response of Nile tilapia (Oreochromis niloticus L.) from different locations to different dietary protein levels. Egypt. J. Aquat. Biol. Fish., 4(4): 295-311.

Lovell, T. (1989). Nutrition and Feeding of Fish. An AVI Book, Published by Van Nostrand Reinhold, New York, p 260.

Martin, R.M. and Wertheimer, A. (1989). Adult production of chinook salmon reared at different densities and released as two small sizes. Prog. Fish Cult., 51: 194-200.

McGeachin, R.B., Wicklund, R.I., Olla, B.L. and Winton, J.R. (1987). Growth of Tilapia aurea in seawater cages. J. World Aquacult. Soc., 18(1): 31-34. 
Miao, S. (1992). Growth and survival model of redtail shrimp Penaens pencillatus (Alock) according to manipulating stocking density.Bulletin of the Institute of Zo. Academia Sinica,31:1-8.

NRC (National Research Council) (1993). Nutrient requirements of fish. Committee on Animal Nutrition. Board on Agriculture. National. Research Council. National Academy Press. Washington DC., USA. p 114.

Ofojekwu, P.C. and Ejike, C. (1984): Growth response and feed utilization in the tropical cichlid Oreochromis niloticus fed on cotton seed based artificial diets. Aquacult., 42: 27-36.

Omar, E.; Al-Sagheer, F.M.; Nour, A. M.., and Abou-Akkada, A.R. (1997). Effect of protein level and stocking density on growth performance, feed utilization and resistance of Nile tilapia (Oreochromis niloticus) to infection against Aeromonas septicemia (Aeromonas hydrophila). In: Feed-Tomorrow's Fish. Proceedings of the Workshop of the CIHEAM Network on Technology of Aquaculture in the Mediterranean (TECAM), A.Tacon and B.Basurco (eds.), Vol. 22, pp 67-77, Zaragoza, Spain, 24-26 June 1996.

Papst, M.H.; Dick, T.A., Arnason, A.N. and Engel, C.E. (1992). Effect of rearing density on the early growth and variation in growth of juvenile Arctic charr, Salvelinus alpinus (L.). Aquacult. Fish. Manag., 23: 41-47.

Rosa, P.V., Costa, P.M.A., Souza, J.R.D., Pereira, J.A.A. and Costa, C.L.S. (1990). Performance and determination of the ideal Nile tilapia density, fed swine excrements. Revista Da Sociedae Brasileira De Zooltecnia, 19: 530-541.

Siddiqui, A.Q.; Howlader, M.S. and Adam, A.B. (1989). Culture of Nile tilapia, Oreochromis niloticus (L.), at three stocking densities in outdoor concrete tanks using drainage water. Aquacult. Fish. Manag., 20: 49-58.

Silva, P.C.; Souza, V.L.; Padua, D.M.C.; Dalacorte, P.C. and Goncalves, D.C. (2000). Effect of stocking density on growth and fillet composition of tetra hybrid red tilapia, Israeli strain. In: Tilapia Aquaculture in the $21^{\text {st }}$ Century. Proceedings from the $5^{\text {th }}$ International Symposium on Tilapia Aquaculture, $\mathrm{K}$. 
Effect of protein level and stocking density on growth 207 performance, survival rate, feed utilization and body composition of Nile tilapia fry (Oreochromis niloticus L.)

Fitzsimmons and J.C. Filho (eds.). Vol. 2, pp 341-345, 3-7 Sept. 2000, Rio de Janeiro, Brazil.

Smith, H.T.; Schreck, C.B. and Maughan, O.E. (1978). Effect of population density and feeding rate on the fathead minnow (Pimephales promelas). J. Fish Biol., 12: 449-455.

Snedecor, G.W. and Cochran, W.G. (1982). Statistical methods. 6th edition. Iowa State Univ. Press, Ames, IA, USA, pp 593.

Tacon A.G.I. (1987). The nutrition and feeding of farm fish and shrimp a training manual. 1. The essential nutrients. FAO Brasilia Brazil, GCP/RLA/075/ITA Field Document 2/E, pp. 117.

Wallace, J.C; Kolbeinshavn, A.G. and Reinsnes, T.G. (1988). The effects of stocking density on early growth in Arctic charr, Salvelinus alpinus (L.). Aquacult., 73: 1-4.

Watanabe, W.O.; Clark, J.H.; Dunhkam, J.B.; Wicklund, R.I. and Olla, B.L. (1990). Culture of Florida red tilapia in marine cages: The effect of stocking density and dietary protein on growth. Aquacult., 90: 123-134. 
Table 1: Ingredients and chemical composition and the experimental diet (on dry matter basis).

\begin{tabular}{|c|c|c|c|}
\hline \multirow[t]{2}{*}{ Ingredients } & \multicolumn{3}{|c|}{ Dietary protein levels } \\
\hline & $25 \%$ & $35 \%$ & $45 \%$ \\
\hline Fish meal & 15.6 & 20.3 & 31.0 \\
\hline Soybean meal & 20.0 & 40.0 & 50.0 \\
\hline Whoat bran & 5.0 & 5.0 & 5.0 \\
\hline Ground corn & 52.63 & 28.42 & 9.44 \\
\hline Fish oil + Corn oil $(1: 1)$ & 2.0 & 2.0 & 2.0 \\
\hline Vitamins \& minerals premix ${ }^{(1)}$ & 1.5 & 1.5 & 1.5 \\
\hline Ascorbic acid & 0.06 & 0.06 & 0.06 \\
\hline Starch & 2.21 & 1.72 & 0.0 \\
\hline Carboxymethyl cellulose & 1.0 & 1.0 & 1.0 \\
\hline Total & 100 & 100 & 100 \\
\hline \multicolumn{4}{|l|}{ Chemical analysis (\%) } \\
\hline Dry matter & $92.48 \pm 0.7$ & $92.69 \pm 0.6$ & $93.09 \pm 0.6$ \\
\hline Crude protein & $25.32 \pm 0.24$ & $35.41 \pm 0.33$ & $45.56 \pm 0.46$ \\
\hline Crude fat & $5.87 \pm 0.15$ & $5.67 \pm 0.25$ & $5.99 \pm 0.20$ \\
\hline Ash & $5.51 \pm 0.23$ & $6.31 \pm 0.36$ & $7.31 \pm 0.37$ \\
\hline Fiber & $6.68 \pm 0.15$ & $5.50 \pm 0.12$ & $5.76 \pm 0.13$ \\
\hline $\mathrm{N}=\mathrm{E}(2)$ & 56.62 & 47.11 & 35.38 \\
\hline $\mathrm{GE}(\mathrm{Kcal} / 100 \mathrm{~g})^{(3)}$ & 439.14 & 446.85 & 458.92 \\
\hline
\end{tabular}

(1) Vitamin \& minerals premix: each $2.5 \mathrm{~kg}$ contain vitamin $\mathrm{A} 12 \mathrm{MIU} ; \mathrm{D}_{3} 2 \mathrm{Ml} \mathrm{U}, \mathrm{E} 10 \mathrm{~g}$; $\mathrm{K} 2 \mathrm{~g} ; \mathrm{B}_{1} \quad \mathrm{~g} ; \mathrm{B}_{2} 4 \mathrm{~g} ; \mathrm{B}_{6} \quad 1.5 \mathrm{~g} ; \mathrm{B}_{12} 10 \mathrm{mg}$; Pantothenic acid $10 \mathrm{~g}$; Nicotinic acid $20 \mathrm{~g}$; Folic acid 1g; Biotin $50 \mathrm{mg}$; Choline chloride $500 \mathrm{mg}$; copper $10 \mathrm{~g}$; todine $1 \mathrm{~g}$; iron $30 \mathrm{~g}$; manganese $55 \mathrm{~g}$; zinc $55 \mathrm{~g}$ and selenium $0.1 \mathrm{~g}$.

(2) NFE (nitrogen free extract) $=100-$ (protein + lipid + ash + fiber)

(3) GE (gross energy): Calculated after NRC (1993) as 5.64, 9.44 and 4.11 Kcal/g for protein, lipid and NFE, respectively. 
Table 2. Different growth parameters of Nile tilapia (O. niloticus) fed different levels of dietary protein at two stocking densities (with 2-way ANOVA).

\begin{tabular}{|c|c|c|c|c|c|c|}
\hline \multirow[t]{3}{*}{ Items } & \multicolumn{6}{|c|}{ Treatments } \\
\hline & \multicolumn{2}{|c|}{$25 \% \mathrm{CP}$} & \multicolumn{2}{|c|}{$35 \%$ CP } & \multicolumn{2}{|c|}{$45 \% \mathrm{CP}$} \\
\hline & S1 & $\mathrm{S2}$ & S1 & S2 & S1. & S2 \\
\hline $\begin{array}{l}\text { Final weight } \\
\text { (g/fish) }\end{array}$ & $\begin{array}{l}7.0 \mathrm{~cd} \\
\pm 0.14\end{array}$ & $\begin{array}{r}6.4 d \\
\pm 0.17\end{array}$ & $\begin{array}{r}8.9 \mathrm{~b} \\
\pm 0.23\end{array}$ & $\begin{array}{r}7.6 \mathrm{c} \\
\pm 0.09\end{array}$ & $\begin{array}{l}10.1 \mathrm{a} \\
\pm 0.03\end{array}$ & $\begin{array}{r}9.1 \mathrm{~b} \\
\pm 0.43\end{array}$ \\
\hline $\begin{array}{l}\text { Weight gain } \\
\text { (g/fish) }\end{array}$ & $\begin{array}{l}4.9 \mathrm{~cd} \\
\pm 0.16\end{array}$ & $\begin{array}{r}4.3 \mathrm{~d} \\
\pm 0.17\end{array}$ & $\begin{array}{r}6.8 b \\
\pm 0.23\end{array}$ & $\begin{array}{r}5.5 \mathrm{c} \\
\pm 0.09\end{array}$ & $\begin{array}{r}8.0 \mathrm{a} \\
\pm 0.07\end{array}$ & $\begin{array}{r}7.0 \mathrm{~b} \\
\pm 0.43\end{array}$ \\
\hline Wt. gain \% & 233.3 & 204.8 & 323.8 & 261.9 & 381.0 & 333.3 \\
\hline S G R (\%) & $\begin{array}{l}1.720 d \\
\pm 0.032\end{array}$ & $\begin{array}{l}1.591 d \\
\pm 0.041\end{array}$ & $\begin{array}{c}2.063 b \\
\pm 0.04\end{array}$ & $\begin{array}{r}1.837 c \\
\pm 0.016\end{array}$ & $\begin{array}{r}2.344 \mathrm{a} \\
\pm 0.016\end{array}$ & $\begin{array}{l}2.094 \mathrm{ab} \\
\pm 0.069\end{array}$ \\
\hline K factor (\%) & $\begin{array}{l}1.563 \mathrm{ab} \\
\pm 0.008\end{array}$ & $\begin{array}{r}1.617 \mathrm{a} \\
\pm 0.023\end{array}$ & $\begin{array}{l}1.497 b c \\
\pm 0.026\end{array}$ & $\begin{array}{l}1.560 \mathrm{ab} \\
\pm 0.006\end{array}$ & $\begin{array}{l}1.497 \mathrm{bc} \\
\pm 0.031\end{array}$ & $\begin{array}{l}1.530 \mathrm{bc} \\
\pm 0.005\end{array}$ \\
\hline Survival (\%) & $\begin{array}{l}93.3 \mathrm{a} \\
\pm 1.9\end{array}$ & $\begin{array}{l}93.3 \mathrm{a} \\
\pm 2.2 \\
\end{array}$ & $\begin{array}{l}93.3 \mathrm{a} \\
\pm 2.2\end{array}$ & $\begin{array}{r}95.6 \mathrm{a} \\
\pm 1.13\end{array}$ & $\begin{array}{l}96.7 \mathrm{a} \\
\pm 2.2\end{array}$ & $\begin{array}{l}96.7 \mathrm{a} \\
\pm 1.9\end{array}$ \\
\hline
\end{tabular}

Initial weight was $2.1 \mathrm{~g} / \mathrm{fish}$.

$\mathrm{S} 1=15 \mathrm{fish} / 100 \mathrm{~L} ; \mathrm{S} 2=30 \mathrm{fish} / 100 \mathrm{~L}$.

The same letter in the same row is not significantly different at $\mathrm{P}<0.05$.

ANOVA

\begin{tabular}{|lc|c|c|c|c|c|}
\hline Source df & \multicolumn{6}{|c|}{ Mean square } \\
\cline { 3 - 7 } & & Final wt. & Gain & SGR & K factor & $\begin{array}{c}\text { Survival } \\
\text { rate }\end{array}$ \\
\hline St & 1 & $4.11^{* *}$ & $3.83^{* *}$ & $0.097^{* *}$ & 0.004 & 30.42 \\
Pr & 2 & $12.35^{* *}$ & $11.94^{* *}$ & $0.387^{* *}$ & $0.0104^{*}$ & 17.31 \\
Pr x St & 2 & 0.22 & 0.22 & 0.005 & 0.0048 & 2.42 \\
Error & 12 & 0.1506 & 0.1522 & 0.0049 & 0.0013 & 16.667 \\
\hline
\end{tabular}

$\mathrm{St}=$ stocking density; $\mathrm{Pr}=$ protein level.

$* \mathrm{P}<0.05$; * $\mathrm{P}<0.01$. 
Table 3. Feed intake, feed conversion ratio (FCR), protein efficiency ratio (PER) and protein productive value (PPV) of Nile tilapia (O. niloticus) fed different dietary protein levels at two stocking densities (with 2-way ANOVA).

\begin{tabular}{|c|c|c|c|c|c|c|}
\hline \multirow{3}{*}{ Items } & \multicolumn{6}{|c|}{ Treatments } \\
\cline { 2 - 7 } & \multicolumn{2}{|c|}{$\mathbf{2 5}$ CP } & \multicolumn{2}{c|}{$\mathbf{3 5} \% \mathbf{C P}$} & \multicolumn{2}{c|}{$\mathbf{4 5}$ CP } \\
\cline { 2 - 7 } & $\mathbf{S 1}$ & $\mathbf{S 2}$ & $\mathbf{S 1}$ & $\mathbf{S 2}$ & $\mathbf{S 1}$ & $\mathbf{S 2}$ \\
\hline Feed intake & $10.8 \mathrm{~b}$ & $10.7 \mathrm{~b}$ & $12.7 \mathrm{ab}$ & $11.6 \mathrm{ab}$ & $14.9 \mathrm{a}$ & $13.4 \mathrm{a}$ \\
(g feed/fish) & \pm 0.22 & \pm 0.33 & \pm 0.13 & \pm 0.15 & \pm 1.45 & \pm 0.35 \\
& & & & & & \\
FCR & $2.25 \mathrm{~b}$ & $2.46 \mathrm{a}$ & $1.81 \mathrm{de}$ & $2.07 \mathrm{c}$ & $1.72 \mathrm{e}$ & $1.89 \mathrm{~d}$ \\
& \pm 0.02 & \pm 0.01 & \pm 0.06 & \pm 0.02 & \pm 0.05 & \pm 0.06 \\
& & & & & & \\
PER & $1.913 \mathrm{a}$ & $1.720 \mathrm{~b}$ & $1.623 \mathrm{~b}$ & $1.467 \mathrm{c}$ & $1.340 \mathrm{~cd}$ & $1.250 \mathrm{~d}$ \\
& \pm 0.052 & \pm 0.052 & \pm 0.049 & \pm 0.043 & \pm 0.040 & \pm 0.035 \\
& & & & & & \\
PPV (\%) & $30.54 \mathrm{a}$ & $26.64 \mathrm{~b}$ & $24.82 \mathrm{~b}$ & $22.25 \mathrm{c}$ & $20.88 \mathrm{~cd}$ & $19.82 \mathrm{~d}$ \\
& \pm 0.88 & \pm 0.77 & \pm 0.72 & \pm 0.64 & \pm 0.60 & \pm 0.57 \\
\hline
\end{tabular}

$\mathrm{S} l=15 \mathrm{fish} / 100 \mathrm{~L} ; \mathrm{S} 2=30 \mathrm{fish} / 100 \mathrm{~L}$.

The same letter in the same row is not significantly different at $\mathbf{P}<0.05$.

ANOVA

\begin{tabular}{|lc|c|c|c|c|}
\hline Source & df & \multicolumn{5}{|c|}{ Mean square } \\
\cline { 3 - 6 } & & $\begin{array}{c}\text { Feed } \\
\text { intake }\end{array}$ & FCR & PER & PPV \\
& 1 & 0.281 & $0.216^{* *}$ & $0.097^{* *}$ & $28.4^{* *}$ \\
St & 1 & $0.998^{* *}$ & $0.501^{* *}$ & $0.408^{* *}$ & $103.5^{* *}$ \\
Pr & 2 & 0.969 & 0.003 & 0.004 & 3.01 \\
Prx St & 12 & 1.2128 & 0.0051 & 0.0064 & 1.4919 \\
Error & 12 &
\end{tabular}

$\mathrm{Si}=$ stocking density; $\mathrm{Pr}=$ protein level.

* $\mathrm{P}<0.05$; * $\mathrm{P}<0.01$. 
Table 4. Proximate chemical analysis (\%; on dry matter hasis) of Nile dilapia (O.niloticus) fed different protein levels at two stocking densities (with 2-way ANOVA).

\begin{tabular}{|c|c|c|c|c|c|c|c|}
\hline \multirow{3}{*}{$\begin{array}{c}\text { Items } \\
\%\end{array}$} & \multirow[t]{3}{*}{ Initial } & \multicolumn{6}{|c|}{ Treatments } \\
\hline & & \multicolumn{2}{|c|}{$25 \% \mathrm{CP}$} & \multicolumn{2}{|c|}{$35 \% \mathrm{CP}$} & \multicolumn{2}{|c|}{$45 \% \mathrm{CP}$} \\
\hline & & S1 & S2 & S1 & $\mathbf{5 2}$ & S1 & S2 \\
\hline Moisture & $\begin{array}{r}75.5 \\
\pm 0.35\end{array}$ & $\begin{array}{r}71.8 \mathrm{c} \\
\pm 0.23\end{array}$ & $\begin{array}{c}72.9 \mathrm{bc} \\
\pm 0.31\end{array}$ & $\begin{array}{c}73.5 \mathrm{ab} \\
\pm 0.88\end{array}$ & $\begin{array}{r}74.5 \mathrm{a} \\
\pm 0.49\end{array}$ & $\begin{array}{l}73.8 \mathrm{ab} \\
\pm 0.39\end{array}$ & $\begin{array}{l}73.4 \mathrm{ab} \\
\pm 0.38\end{array}$ \\
\hline $\begin{array}{l}\text { Crude } \\
\text { protein }\end{array}$ & $\begin{array}{c}55.9 \\
\pm 0.17\end{array}$ & $\begin{array}{l}54.34 \mathrm{c} \\
\pm 0.33\end{array}$ & $\begin{array}{l}55.0 \mathrm{c} \\
\pm 0.10\end{array}$ & $\begin{array}{l}56.5 b \\
\pm 0.29\end{array}$ & $\begin{array}{l}57.7 a \\
\pm 0.23\end{array}$ & $\begin{array}{r}58.0 \mathrm{a} \\
\pm 0.15\end{array}$ & $\begin{array}{r}57.9 a \\
\pm 0.34\end{array}$ \\
\hline $\begin{array}{c}\text { Ether } \\
\text { extract }\end{array}$ & $\begin{array}{c}30.3 \\
\pm 0.17\end{array}$ & $\begin{array}{r}32.8 \mathrm{a} \\
\pm 0.07\end{array}$ & $\begin{array}{c}31.0 \mathrm{ab} \\
\pm 0.32\end{array}$ & $\begin{array}{c}28.83 b c \\
\pm 0.56\end{array}$ & $\begin{array}{c}27.6 \mathrm{~cd} \\
\pm 0.54\end{array}$ & $\begin{array}{l}26.3 \mathrm{~d} \\
\pm 1.64\end{array}$ & $\begin{array}{l}25.2 \mathrm{~d} \\
\pm 0.36\end{array}$ \\
\hline Ash & $\begin{array}{c}13.8 \\
\pm 0.29\end{array}$ & $\begin{array}{l}13.0 \mathrm{~d} \\
\pm 0.54\end{array}$ & $\begin{array}{l}13.9 \mathrm{~cd} \\
\pm 0.17\end{array}$ & $\begin{array}{l}14.7 \mathrm{c} \\
\pm 0.13\end{array}$ & $\begin{array}{l}14.6 \mathrm{c} \\
\pm 0.23\end{array}$ & $\begin{array}{l}15.6 b \\
\pm 0.20\end{array}$ & $\begin{array}{l}16.8 \mathrm{a} \\
\pm 0.10\end{array}$ \\
\hline
\end{tabular}

$\mathrm{Sl}=15 \mathrm{fish} / 100 \mathrm{~L} ; \mathrm{S} 2=30 \mathrm{fish} / 100 \mathrm{~L}$.

The same letter in the same row is not significantly different at $\mathrm{P}<0.05$.

ANOVA

\begin{tabular}{|lc|c|c|c|c|}
\hline Source & df & \multicolumn{4}{|c|}{ Mean square } \\
\cline { 3 - 6 } & & Moisture & $\begin{array}{c}\text { Crude } \\
\text { protein }\end{array}$ & $\begin{array}{c}\text { Total } \\
\text { lipids }\end{array}$ & Ash \\
\hline St & $\mathbf{1}$ & 1.614 & $1.572^{*}$ & $8.36^{*}$ & $1.29^{*}$ \\
$\mathbf{P r}$ & $\mathbf{2}$ & $4.658^{*}$ & $17.11^{* *}$ & $57.04^{* *}$ & $10.09^{* *}$ \\
$\mathbf{P r} \times$ St & $\mathbf{2}$ & 1.035 & 0.671 & 0.242 & 0.601 \\
Error & $\mathbf{1 2}$ & 0.7283 & 0.197 & 1.755 & 0.2198 \\
\hline
\end{tabular}

$\mathrm{St}=$ stocking density; $\mathrm{Pr}=$ protein level.

${ }^{*} \mathrm{P}<0.05$; * $\mathrm{P}<0.01$. 